Seamus Heaney 
For my dear friend Kyle Irwin, who was brought back from the dead. Deo Soli Gloria. 


\section{Seamus Heaney}

An Introduction

Richard Rankin Russell

EDINBURGH

University Press 
Edinburgh University Press is one of the leading university presses in the UK. We publish academic books and journals in our selected subject areas across the humanities and social sciences, combining cuttingedge scholarship with high editorial and production values to produce academic works of lasting importance. For more information visit our website: edinburghuniversitypress.com

(C) Richard Rankin Russell, 2016

Edinburgh University Press Ltd

The Tun - Holyrood Road

12(2f) Jackson's Entry

Edinburgh EH8 8PJ

Typeset in 10.5/13 Adobe Sabon by Servis Filmsetting Ltd, Stockport, Cheshire, printed and bound in Great Britain by CPI Group (UK) Ltd, Croydon CR0 4YY

A CIP record for this book is available from the British Library

ISBN 9781474401654 (hardback)

ISBN 9781474401678 (webready PDF)

ISBN 9781474401661 (paperback)

ISBN 9781474401685 (epub)

The right of Richard Rankin Russell to be identified as the author of this work has been asserted in accordance with the Copyright, Designs and Patents Act 1988, and the Copyright and Related Rights Regulations 2003 (SI No. 2498). 